\title{
Bioremediation of Ammonia from Polluted Waste Waters- A Review
}

\author{
Sheela. $\mathbf{B}^{1, *}$, Khasim Beebi. $\mathbf{S k}^{2}$ \\ ${ }^{1}$ Department of biotechnology, Gitam institute of science, Gitam University, Visakhapatnam, India \\ ${ }^{2}$ Department of biotechnology, Gitam institute of Technology, Gitam University, Visakhapatnam, India \\ *Corresponding author: sheela_bethapudi@yahoo.com
}

Received September 20, 2014; Revised October 20, 2014; Accepted November 13, 2014

\begin{abstract}
Global water pollution due to industries became a major concern now. Some industrial facilities generate ordinary domestic sewage that can be treated in municipal sewage systems whereas industries that generate waste waters high in conventional pollutants like ammonia need exclusive treatments for their removal from the effluents before discharging. Ammonia can be removed by means of physical, chemical, biological methods. Out of all the methods, bioremediation appears as a promising tool for ammonia pollution as it is a cost effective and converts ammonia into harmless dinitrogen gas. This paper mainly focuses on bioremediation methods available for the removal of ammonia form the industrial effluents and their drawbacks.
\end{abstract}

Keywords: ammonia pollution, biological methods, SND, Anammox, parameters

Cite This Article: Sheela. B, and Khasim Beebi. Sk, "Bioremediation of Ammonia from Polluted Waste Waters- A Review." American Journal of Microbiological Research, vol. 2, no. 6 (2014): 201-210. doi: 10.12691/ajmr-2-6-6.

\section{Introduction}

Ammonia is a compound of nitrogen and hydrogen with the formula of $\mathrm{NH}_{3}$. Ammonia is used either directly or indirectly in industries. Even though its wide use, it is caustic and hazardous in nature. Ammonia nitrogen discharges from municipal, industrial and agricultural wastewater sites, which subsequently mixes into water resources. The raw water with high ammonia concentration must be treated before it reaches the consumer and also the wastewater discharged into the receiving water bodies. The most widely used methods for ammonia removal from wastewaters are adsorption, chemical precipitation, reverse osmosis, air stripping, ion exchange, breakpoint chlorination and biological nitrification and denitrification (Mectcalf and Eddy, 2003). Advanced oxidation processes (AOPs) such as direct photo oxidation (Wang. A. et al; 1994), ozone oxidation (Holgne. J. et al; 1978, Yang. M. et al; 1999), photocatalytic oxidation (Bravo. A. et al; 1993, Bonsen. E.M. et al; 1997, Gootzen. J.F.E et al., 1998, Zhu. X.; et al; 2005) electrochemical oxidation (Della monica. M. et al; 1980, Kim. K. et al; 2006). In oxidation process, the end product is nitrate which is more toxic to aquatic life. Each of these methods have disadvantages like most prominently, costs are too high, since a continuous input of expensive chemical reagents are required to maintain the operation of most AOPs systems. Conventional wastewater treatment technologies are expensive to build and also have associated operational and maintenance problems. For example, by air stripping method, it is feasible to reduce ammonia level to $1 \mathrm{mg} / \mathrm{L}$ but special requirements of the process such as water temperature of over $15^{\circ} \mathrm{C}$ and carbonate deposition are disadvantages of this system. Thus both physic-chemical and biological technologies have been applied for the elimination of ammonia from wastewaters for long period (Bonmati and Flotats., 2002, Sugiyami et al; 2005). However, with the ever stringent discharge limits of ammonia and nitrate (50 $\mathrm{mg} / \mathrm{L} \mathrm{NH4-N,} 10 \mathrm{mg} / \mathrm{L} \mathrm{NO3-N)}$ for inland surface waters, it is essential to remove them to permissible levels. Biotreatment, being cost effective, is normally adopted for wastewater treatments. There are many advantages of bioremediation over conventional methods. Here in this review overall biological methods used for ammonia removal and the factors which effects the ammonia removal from the polluted waters was discussed.

\section{Biological Process for Ammonia- Nitrogen Removal}

\subsection{Nitrification/Denitrification}

Biological autotrophic nitrification followed by heterotrophic denitrification has long been applied for municipal and industrial wastewaters. For application of industrial wastewaters it becomes very difficult as composition and characteristics of effluents varies from industry to industry and even day to day. Under strict aerobic conditions, complete nitrification is carried out in two sequential oxidative stages-ammonia is first converted to nitrite by ammonia oxidizing bacteria and this nitrite is again converted into nitrate by nitrite oxidizing bacteria. 
Each of the oxidizing steps is carried out by different genera of bacteria which use ammonia or nitrite as electron acceptor, while carbon dioxide is used as carbon source. The most common genus of bacteria that carries out ammonia oxidation is Nitrosomonas species. Ammonia oxidizers are genetically diverse but related to each other and are found in the beta subdivision of proteobacteria. The nitrite oxidation is carried out by Nitrospina, Nitrospina, Nitrococcus, and Nitrocystis. The most known genus of nitrite oxidizer is Nitrobacter which is genetically closely related to alpha subdivision of proteobacteria (Rittmann B.E., 2001). In the subsequent process denitrification is performed by heterotrophic denitrifiers under anoxic conditions. The oxidized nitrogenous compounds (nitrite or nitrate) are reduced to gaseous nitrogen by heterotrophic microorganisms that use nitrite or nitrate instead of oxygen as electron acceptor and organic matter as carbon and energy. Denitrification is common among the gram negative bacteria such as Pseudomonas, Alcaligenes, Paracoccus and Thiobacillus. Some gram positive bacteria (like Bacillus) and a few halophillic archaeal microorganisms (Haloferax denitrificans) are able to denitrify (Kim et al., 2005, Cyplik et al., 2007). Denitrifiers are ubiquitous in nature (Szekeres et al., 2005) and several researchers cultivated them using mixed cultures taken from wastewater treatment plants as seed. Denitrification is a slow process particularly for industrial wastewaters that contains high concentrations of nitrate (Foglar et al., 2005) but the process gained huge interest as it is environment friendly and cost effective. Organic carbon sources used for heterotrophic denitrification include both solid and liquid form but mostly aqueous forms are used for wastewater treatment plants. Among the most common form of carbon source are methanol, ethanol and acetic acid which are used for wastewaters and drinking waters (Gomez et al., 2003, Osaka et al., 2008, Feleke et al., 2002). A combination of carbon source using methanol and acetic acid gave better results for nitrogen removal and also showed better settling of sludge compared to use methanol and acetic acid alone (Cho et al., 2004). A lot of research work is going on to speed up the denitrification process through different strategies in which better contact of nitrate with microorganisms in wastewaters was maintained such as packed bed reactors (Daniel et al., 2009), rotating biological contactors (Teixeira et al., 2005), membrane biofilm reactor (Tereda et al., 2006).

\subsection{Simultaneous Nitrification Denitrification}

SND process starts with the partial nitrification of ammonia and to nitrite and subsequently continuous with a direct reduction nitrite to nitrogen gas (Jenicek et al., 2004, Lai et al., 2004). This process is operated in a single stage with identical operational conditions which reduces large reactor volumes and energy costs for recirculation that are required for aerobic and anoxic systems. Several research units have been proposed for SND process in a single reactor (Guo et al., 2005) and Zhang et al., introduced a flexible biofilm reactor with adjustable aerobic, buffer and anoxic zones with liquid circulation being dependent on aeration flow rate and both the experiments were successful providing proof for possibility of SND in a single reactor. In SND process optimum $\mathrm{pH}$ can be maintained without the addition of acid or base as the optimum $\mathrm{pH}$ for nitrifiers and denitrifiers lies between 7 and 8.5 (Chang et al., 1999) and it also reduces cost for $\mathrm{pH}$ alterations. Polymeric beads, in which nitrifiers and denitrifiers were immobilized, were used to remove nitrogen and ammonia from wastewaters in a single step. Uemoto and saiki et al., 2000, investigated a novel immobilized cell bioreactor containing packed gel envelopes capable to carryout SND process. The packed gel envelopes consisted of two polymeric gel plates with an internal space for injecting electron donor for denitrification. Ammonia oxidizer Nitrosomonas europaea and a denitrifier namely Paracoccus denitrificans were co-immobilized in a plate gel. The immobilized N.europaea oxidizes ammonia to nitrite on the outer surface of the plate that was in aerobic contact with wastewater containing ammonia, immobilized P.denitrificans reduce nitrite to nitrogen gas on the inside of the plate that was in anaerobic contact with the electron donor. Additional aeration step was not required for this process as electrons were directly injected into the internal space between the plates. This resulted in increase in utilization of electron donor for denitrification process and decrease in sludge quantity was observed. In further attempt, a 30 packed gel envelopes were implemented for thermal power plant for the removal of nitrogen from ammonia containing desulfurization wastewater. The reactor achieved 95\% nitrogen removal with continuous wastewater system and the outlet concentration was $9 \mathrm{mg}$ N/L (Morita et al., 2008). Cao et al., 2004 constructed a shell and tube co-immobilized bioreactor in which PVA material was used as immobilizing media and it was stable even after 3 months of operation proving an excellent option for nitrogen removal from wastewaters. Sun.J et al., in 2011 compared PVA and sodium alginate with immobilized nitrifiers and found PVA showed better results compared to sodium alginate beads. Though sodium alginate showed poor mechanical strength its mass transfer capacity was excellent than PVA. Recent research in immobilization field showed PVA as suitable material for ammonia remediation work. Agglomeration is the big problem with PVA material but this can be resolved by incorporation with cellulosic polymers (Antczak.M and Galas.E in 2009).

\subsection{Autotrophic Nitrification/Denitrification}

Generally conventional biological nitrogen removal process is used for treating wastewaters with relatively low nitrogen concentrations (Total nitrogen concentrations less than $100 \mathrm{mgN} / \mathrm{L}$ ). Mulder.A. (2003) stated that biological treatment by autotrophic nitrogen removal is to be preferred for concentrated wastewater streams with high ammonia concentrations in the range of 100-5000 $\mathrm{mgN} / \mathrm{L}$. Autotrophic denitrifiers utilize inorganic carbon compounds (carbon dioxide or bicarbonate) as a sole source of carbon. Autotrophic denitrification is more advantageous than heterotrophic denitrification due to low biomass yield, sludge production is very low resulting in the reduction of reactor clogging and easier post treatment (Rijn et al., 2006). A lot of research work has been done on elemental sulphur (Zeng et al., 2005, Wan et al., 2009) 
and hydrogen (Mansell et al., 2002, Rezania et al., 2007) as an electron donor for autotrophic denitrification. In general Thiobacillus denitrificans and Thiomicrospira denitrificans are the two most autotrophic denitrifiers commonly reported (Brettar et al., 2006). In nature these microorganisms encounter both heterotrophic and autotrophic denitrification. In bench scale studies, nitrified wastewater was denitrified by Thiobacillus denitrificans in packed bed reactors containing elemental sulphur (Koenig et al., 2001). The feasibility of autotrophic denitrification was investigated and it was accomplished that its applicability depends on costs of sulphur and methanol (Quan et al., 2005). It was noted that autotrophic denitrification may be more stable than some heterotrophic systems during transient nitrate loadings. In heterotrophic systems addition of carbon source must be controlled to prevent over and under dosing but in case of autotrophic denitrification addition of elemental sulphur in excess may remain within the reactor in the solid form.

\subsection{Nitrification /Denitrification via Nitrite Pathway}

To meet ever stringent discharge standards, new technologies and application strategies for the removal of ammonia from wastewaters have been implemented. Partial nitrification to nitrite was reported to be technically feasible and economically favorable especially when wastewaters containing high ammonia concentrations with low $\mathrm{C} / \mathrm{N}$ ratio are treated. Various novel biological processes such as short cut nitrification and denitrification, anaerobic ammonia oxidation, completely autotrophic removal over nitrite (CANON), oxygen limited autotrophic nitrification and denitrification (OLAND), have been developed (Verstraete and Philips 1998). Partial nitrification is a critical procedure as nitrite acts as an intermediary substrate (Philips et al., 2002). Out all the process only SHARON process gained interest due to its successful operation in practical. Partial nitrification and denitrification via nitrite depends on the factor partial nitrification up to nitrite is followed by nitrite denitrification. Partial nitrification can be selectively obtained by inhibiting nitrite oxidizing through appropriate regulation of the systems DO concentration, SRT, pH, temperature, substrate concentration and load, operation and aeration pattern, and inhibitors. SHARON process is the first successful process in which nitrification and denitrification via nitrite as an intermediate has been achieved under stable conditions and operated in full-scale operation (Mudler et al., 2001). Corral et al., (2001) studied the effect of salts and acetate on the SHARON bioreactor treating ammonia rich wastewaters. The study demonstrated acetate concentrations above $0.3 \mathrm{mg}$ TOC/L and salt concentration above $100 \mathrm{mM}$ resulted inhibition of nitrification in ammonia rich wastewaters. However the operation conditions for SHARON, such as high temperature and high ammonium concentrations, limits its development and application (STOWA, 1995). This process can only be applied to stage on rejection water of sludge digestion and leachate of landfill site. To date only successful operation was achieved in sequence operation and a few was with continuous flow process (Peng et al., 2003a).

\subsection{Anammox Bacteria}

The anammox process was first described in bioreactors of wastewater treatment plants (Van de graaf et al., 1995, Mudler et al., 1995) where ammonium reacts with nitrite to produce dinitrogen gas.

$$
\mathrm{NH}_{4}{ }^{+}+\mathrm{NO}_{2}{ }^{-} \rightarrow \mathrm{N}_{2}+2 \mathrm{H}_{2} \mathrm{O}
$$

This process attained special attention as it is an efficient biological alternative to the conventional nitrification and denitrification for the nitrogen removal from wastewaters. In comparison to conventional nitrification and denitrification, Anammox bacteria requires no external carbon source, they take carbon dioxide from water, 50\% less oxygen, therefore low operation costs (Tal et al., 2006). These bacteria belong to the order planctomycetales. They are the most primitive group of bacteria and occupy the base of the bacterial tree. They are gram negative, uncultivable, first isolated through density gradient centrifugation (Van de graaf et al., 1996, Strous et al., 2002). Their distinctive phenotypic characteristics involve red color, budding production, crateriform structure on the cell surface, intracellular compartment, anammoxosome, intra cytoplasmic membrane containing ladder lane lipids (Van de graaf et al., 1996, Linsey et al., 2001, Sininghe Damste et al., 2002). They have a coccoid shape with a diameter of less than $1 \mu \mathrm{m}$ and generation time of 10-30 days (Van Niftrik et al., 2004). The Anammox bacteria are characterized by their slow growth rate and low biomass yield (Strous et al., 1998).they have relatively high affinity for the substrates. Nitrite is more toxic to them than ammonium in a $\mathrm{pH}$ range of 6.7-8.3 (Strous et al., 1999b, Dapena mora et al., 2007). The Anammox bacteria can with stand partial oxygen pressure lower than $0.5 \%$ air saturation. At high levels of dissolved oxygen concentrations $(>18 \%)$, the biological reaction becomes irreversible (Strous et al., 1997, Egli et al., 2001). Table 1 show Anammox bacteria discovered up to date.

\begin{tabular}{|c|c|c|}
\hline Genus & Species & Sources \\
\hline Brocadia & $\begin{array}{c}\text { Candidatus Brocadia anammoxidans } \\
\text { (Strous et al., 1999a) } \\
\text { Candidatus Brocadia fulgida (Kartal et } \\
\text { al., 2004) }\end{array}$ & $\begin{array}{l}\text { Wastewater } \\
\text { Wastewater }\end{array}$ \\
\hline Kuenenia & $\begin{array}{l}\text { Candidatus Kuenenia stuttgartiensis } \\
\text { (Penton et al., 2006) }\end{array}$ & Wastewater \\
\hline Scalindua & $\begin{array}{c}\text { Candidatus scalindua brodae (Schmid et } \\
\text { al., 2003) } \\
\text { Candidatus scalindua wagneri (Schmid } \\
\text { et al., 2003) } \\
\text { Candidatus scalindua sorokinii (Schmid } \\
\text { et al., 2003) }\end{array}$ & $\begin{array}{l}\text { Wastewater } \\
\text { Wastewater } \\
\text { Sea water }\end{array}$ \\
\hline Others & $\begin{array}{c}\text { Candidatus jettenia asiatica (Tsushima } \\
\text { et al., 2007) } \\
\text { Candidatus anammoxoglobus } \\
\text { propionicus (Kartal et al., 2007) } \\
\end{array}$ & $\begin{array}{l}\text { Not specified } \\
\text { Synthetic } \\
\text { wastewater }\end{array}$ \\
\hline
\end{tabular}

\subsection{Anammox Process}

Industrial application of anammox process is still limited due its slow growth rate and low yield of anammox biomass. Even a slight loss of biomass during washout with the effluent could reinitiate the start up period. Due to this condition, it is highly recommended to use a reactor with high biomass retention capacity. Till now a large range of bioreactors were studied for the 
cultivation of anammox bacteria which are fluidized bed reactors, SBR, gas lift reactors, fixed bed reactors, UASB reactors (wyffels et al., 2004, strous et al., 2002). Out of all the reactors sequencing batch reactor (SBR) was found to be suitable for anammox culturing for its efficient biomass retention, stability and reliability for its long term operation, simple operation, stable under substrate limiting condition and high nitrogen conversion (van dongen et al., 2001, jetten et al., 1993, strous et al., 1998). Strous et al (1997) conducted experiments with FBR and fixed bed reactor with sand and glass particles as supporting media for Anammox bacteria but could not prevent biomass loss floating sludge caused by entrapped gas bubbles. Dapena mora et al stated that mechanical stirring in SBR could effectively solve the gas entrapped in the granules compared less abrasive stress in gas lift reactor and further more use of non-woven fibers can increase the biomass retention. It was proven in several studies that use of non-woven fibers demonstrated a short startup period and high nitrogen removal rates (Van niftrik et al., 2004, Isaka et al., 2006). Van der star (2008) stated that MBR is a powerful tool for anammox research as high production of almost pure anammox bacteria can be obtained avoiding the diffusion limitations within the flocs or granules. The efficiency of the anammox process in a bioreactor depends on the biomass retention capacity and availability of substrate concentration in wastewaters. The nitrite concentration is a crucial factor for growth of anammox biomass: a too low nitrite concentration leads to substrate limitation and too high nitrite concentration above $20 \mathrm{mgN} / \mathrm{L}$ can lead to inhibition of the process. Furthermore anammox is an anaerobic process; the absence of oxygen is an essential step for the startup of the reactor. To fasten up the startup period, Slikers et al (2003) used inoculum from fully activated anammox sludge for SBR and their start up period was 14 days.

\subsection{Partial Nitrification/Anammox}

The increase in the costs of wastewater treatment systems are challenged by the novel microbial process like combination of anammox and partial nitrification process in one reactor namely CANON process (Complete Autotrophic Nitrogen removal Over Nitrite) (Third et al., 2001). This combination is a promising new method of removing nitrogen from wastewaters with low $\mathrm{C} / \mathrm{N}$ ratio and high ammonia concentrations (Ciudad et al., 2005). Compared to conventional nitrification and denitrification process, more than $62.5 \%$ less oxygen demand and no organic carbon requirement in combined partial nitrification/anammox process (Feng et al., 2007). In CANON systems, Nitrosomonas like ammonia oxidizing bacteria and planctomycetales like anammox bacteria perform two sequential reactions under oxygen limited conditions (Sliekers et al., 2002). The nitrifiers convert ammonia to nitrite and consume oxygen creating anaerobic conditions for anammox bacteria. The produced nitrite is utilized with the reminder of ammonium by anammox bacteria and converts it into nitrogen gas (Nielsen et al., 2005). Typically in the CANON process the Nitrosomonas like bacteria are active in the outer aerobic region of biofilm and in aggregates, while anammox are active in inner anoxic zone. In this way anammox are protected from oxygen which is consumed in the outer aerobic zone. Oxygen can inhibit anammox activity (Strous et al., 2007). The CANON process has quite sensitive operational characteristics for $\mathrm{DO}$, the nitrogen surface load, biofilm thickness and temperature (Hao et al., 2004). The oxygen mass transfer efficiency from gas to the liquid phase and effective biomass retention are the two key factors for the operation of CANON system (Sliekers et al., 2003). Moreover autotrophic ammonia oxidizers grow slowly than heterotrophic bacteria with which they have to compete for oxygen and if the retention time is not long, they will be washed out of the reactor. The biomass concentration can be increased by recirculation of sludge after sedimentation but limited by the efficiency of the sedimentation of the vessel. To overcome these factors along with environmental factors, immobilization technique was adopted. This became an important confront in order to scale up CANON systems from laboratory to industrial application (Gonz et al., 2007). With the immobilization, biomass can be retained in the reactor without washing out and also provides protection from toxic shocks and adverse temperatures. This helps in maintaining year round treatments (Morita et al., 2007). Immobilized biomass can be divided into naturally attached biomass (Biofilm) and artificially immobilized biomass. Biofilm are widely used for wastewater treatment plants. To avoid particle settlement to the bottom of the reactor, membrane aerated biofilm reactors were developed in which hydrophobic, gas permeable membranes are used for bubble less oxygen transfer (Lapara et al., 2006). Membrane aeration is more advantageous than conventional bubble gas transfer mechanism as gas transfer efficiencies are much higher. In MABR, the micro porous membrane carries two functions: oxygen gas supplemental material and carrier for immobilization media (brindle et al., 1996). It was recently proved that thick membrane aerated biofilm can simultaneously provide favorable conditions for nitrification and denitrification within a single biofilm (Cole et al., 2004). Gong et al.,(2007) developed a new MABR in which a micro porous carbon tube membrane was supported with non-woven fabrics and investigated its feasibility and performance of CANON type process in singe stage autotrophic nitrogen removal to treat the synthetic ammonium rich wastewaters like anaerobic sludge liquid. This reactor supplied air through the micro porous carbon tube to the biofilm supported by the nonwoven fabric. The system worked with partial nitrification and dissolved oxygen consumption in the inner layer and anammox in the outer layer of non-woven fabric realizing feasibility of autotrophic nitrogen in a single reactor. This study demonstrated MABR was an excellent option for single stage autotrophic nitrogen removal. For immobilization technique most commonly gel entrapment is used but natural and synthetic polymers are also been used. Rostron et al., (2001) studied on comparison between kaldnes, linpor, PVA materials for high strength ammonia synthetic wastewaters (500-1000 mg/L) and demonstrated that PVA is an excellent immobilization media for high strength ammonia containing wastewaters. The immobilization media should support and fulfill various criteria's like photo transparency, retention of cellular viability, non toxicity and stability during culturing in medium. Usually immobilization techniques 
are commonly used for immobilizing pure strains because mechanism of the strain can easily be understood (Hill et al., 2008). Immobilization of activated sludge has also been reported (Isaka et al., 2007). Yan et al., (2009) studied partial nitrification and degradation of organics with an immobilized biomass in ammonium rich organic wastewaters. This served as a first step for anammox process with partial nitrification via nitrite. They used four immobilization materials: sodium carboxymethylcellulose, sodium alginate, polyvinyl alcohol and sodium alginate and chitosan for entrapping the biomass. Sodium alginate was selected as best material after comparing the partial denitrification rates and adsorption efficiency.

\subsection{Factors Effecting Ammonia Removal Efficiency}

\subsubsection{Temperature}

When treating sanitary landfill leachate containing an ammonia concentration of over $2200 \mathrm{mg} \mathrm{N} / \mathrm{L}$, were investigated at operating temperatures down to $10^{\circ} \mathrm{C}$. When the operating temperature was decreased from 20$17^{\circ} \mathrm{C}$, an approximate $15 \%$ decrease in denitrification was observed immediately without any noticeable effect on nitrification. With the temperatures below $24^{\circ} \mathrm{C}$, nitrification also stopped and methanol loading rate was decreased progressively. At 100C the system suffered major nitrification and denitrification inhibition. Changes in the operation parameters such as decrease in influent ammonia concentration and methanol loading, with increase of temperature from $10-15^{\circ} \mathrm{C}$ did not improve the system performance (Cannavo et al., 2004). Using pure cultures, the optimum temperature was $35^{\circ} \mathrm{C}$ for $\mathrm{AOB}$ and $38^{\circ} \mathrm{C}$ for NOB (Cameilia and Gunnel 2001). The SHARON process pre mentioned was operated at $35^{\circ} \mathrm{C}$ (Mudler et al., 2001). Present reports show that high temperatures of $28-38^{\circ} \mathrm{C}$ is favorable for nitrogen removal via nitrite due to the fact that specific growth rate of AOB is higher than that of NOB. From the aspect of specific growth rate, only temperatures above $25^{\circ} \mathrm{C}$ are possible for ammonia oxidizers to effectively outcome the nitrite oxidizers (Brouwer et al., 1996). Several authors found that the optimum temperatures for the operation of anammox process was around $30-40^{\circ} \mathrm{C}$ (strous et al., 1999). But most of the operations with anammox process were carried at temperatures higher than $30^{\circ} \mathrm{C}$ (Imajo et al., 2004). Recently it was proved that in a rotating biological contactor established with anammox was successfully operated at temperature around $20^{\circ} \mathrm{C}$ (Cema et al., 2007). Rysgaard et al., (2004) working with east and west coasts of Greenland, observed anammox activity between -2 and $30^{\circ} \mathrm{C}$ and optimum temperature being $12^{\circ} \mathrm{C}$. Similar results were found by Dalsgaard and Thamdrup (2002) working with marine sediments from Skagerrak (Baltic-North sea). These results show that application of anammox process is restricted to effluents with temperatures around $30^{\circ} \mathrm{C}$. Dosta et al., (2008) evaluated the effects of moderately low temperatures on the stability of anammox process. First the short term effects of temperatures on anammox biomass were studied using batch tests and maximum activity was found at temperatures $35-40^{\circ} \mathrm{C}$. Activity tests done at temperatures $45^{\circ} \mathrm{C}$ showed an irreversible loss due to the biomass lysis and temperatures $30-15^{\circ} \mathrm{C}$ was selected for long term study. The system was successfully operated at temperature $18^{\circ} \mathrm{C}$. When temperature was decreased to $15^{\circ} \mathrm{C}$, nitrite accumulation was observed and system lost its stability.

\subsection{2. pH}

$\mathrm{pH}$ plays a key role in biological nitrification and denitrification. Most of the physiological activities of nitrifiers are between $\mathrm{pH}$ 7.3-8.0. Groeneweg et al., 1994 studied on the effect of $\mathrm{pH}$ on ammonia oxidation of Nitrosomonas europaea and observed that maximum ammonia oxidation occurred at $\mathrm{pH} 6.7$ and 7. If the $\mathrm{pH}$ drops less than 6.0 and more than 8.2 cease of nitrification process was observed (princic et al., 1998). Walker et al., (1979) isolated ammonia oxidizing autotrophic nitrifiers from acid soils of Bangladesh and Sri Lanka with $\mathrm{pH}$ 44.5 and found evidence of Nitrosospira nitrification in situ at $\mathrm{pH}$ 4.1. In $2008 \mathrm{Hll}$ and Webster conducted $\mathrm{pH}$ tests on ATCC Strain 25978 Nitrosomonas europaea and determined the optimum $\mathrm{pH}$ was between 7 and 8 for this strain. Usually nitrification process is a $\mathrm{pH}$ sensitive and to maintain reasonable nitrification rates $\mathrm{pH}$ should be maintained from 7-7.2 (USEPA, 1993). Nitrification process also depends on COD loading rates. Presences of high COD levels suppress the nitrification rates in bioreactors. Peyton et al., 2001 stated that complete nitrate reduction at $125 \mathrm{~g} / \mathrm{L}$ of $\mathrm{NaCl}$ and at $\mathrm{pH} 9$ was possible with ATCC strain 700597 Halomonas campisalis in brine solution regenerated from ion exchange resins with $\mathrm{NaCl}$ which contains high concentrations of nitrate which is unattainable to eliminate by conventional biological, chemical and physical processes. Compared to heterotrophic denitrification autotrophic denitrification consumes alkalinity and to control $\mathrm{pH}$ alkalinity should be supplied to the autotrophic denitrification. Mostly in research works sodium bicarbonate is used for alkalinity control. For wastewaters with low alkalinity, large amounts of sodium bicarbonate are required to carry out autotrophic denitrification process. An alternative for elemental sulphur particles is limestone (Koenig et al., 2002).

\subsection{DO Concentration}

Biological nitrification and denitrification demands high rates of aeration as denitrifiers are facultative bacteria that require oxygen as their terminal electron acceptor. Due to this property they accept readily nitrogen oxides in absence of oxygen. In this aspect DO levels plays crucial role in nitrogen removal from industrial effluents. Cost of operation increases with aeration rates. High levels of DO can inhibit denitrification as the bacteria take oxygen over nitrite as terminal electron acceptor and this can influence the nitrogen removal rates (zumft et al., 1997). Although it is necessary to enhance the activity of nitrifiers by providing high DO concentrations in a reactor but denitrifiers are affected. To avoid inhibitory effect on denitrification, operation of reactors at low DO levels should be selected. Experiments were performed on the activated sludge reactors with partial nitrification with different DO levels. Maximum nitrite accumulation was observed between 0.7-1.4 mg/L (Cuidad et al., 2005 and Ruiz et al., 2003). With these experiments, short term 
effects of DO on partial nitrification in batch tests were studied (Cuidad et al., 2005, Park et al., 2004). Many researchers studied on SND process with low dissolved oxygen concentrations and the results revealed that SND is accessible with DO concentrations between 0.2-0.8 mg/L (Kwang ju et al., 2006, Peng et al., 2007). Guo et al (2009) showed that at low DO concentrations AOB were the dominant nitrifying bacteria and none of the NOB were recovered from activated sludge.

\subsection{Effect of Nitrate Concentration}

High nitrate concentrations in wastewaters can inhibit denitrification process and led to termination of denitrification to form $\mathrm{N}_{2} \mathrm{O}$ (Blackmer et al., 1978). A few of the research work has been done on high nitrate wastewaters till now. Denitrification with high nitrate is a rather slow process as it requires enhancement of physical and biological parameters and process must be optimized. For high nitrate concentrations removal pre acclimatization of biomass is required. in support of this aspect Dhamole et al., 2007 developed a process for degradation of high strength nitrate waste wherein the sludge from an effluent treatment plant of $s$ fertilizer industry was acclimated to degrade nitrate waste as high as $9032 \mathrm{ppm}-\mathrm{NO}_{3}-\mathrm{N}$ in a time period of 6 hours.

\subsection{Salinity}

The effect of high salt concentration on biological nitrification and denitrification has been previously studied (Campos et al., 2002). High salt concentrations always shoe impact on nitrification and denitrification activities. It was reported that nitrification and denitrification activities were sustained by gradual acclimatization of fresh water sludge to high salt concentrations. Halophilic denitrifiers were isolated from long term acclimated sludge and higher denitrification rates were achieved with long term acclimated sludge (yoshie et al., 2006). Correl et al (2002) studied on SHARON process in presence of salts and organic carbon and results demonstrated salt concentration above $100 \mathrm{mM}$ inhibited ammonia oxidation in SHARON bioreactor treating fish water effluents. Experiments on characterization of microbial community in an aerobic granular sludge reactor treating wastewaters showed AOB (Nitrosomonas) can sustain salt concentration of 33g/L and while NOB (Nitrosospira) were severely affected (Bassin et al., 2011). However partial nitrification/anammox process can be successfully applied for wide variety wastewaters like livestock wastewaters, landfill leachate, industrial wastewaters etc, but these waters contain high salt concentrations which were considered as an inhibition factors for biological nitrogen removal (van der star et al., 2007). Marine anammox bacteria belong to the genus scalindua have been detected in natural surroundings (Schmid et al., 2007) and recently they were enriched in continuous culture system for more than one year (Van de vossenberg et al., 2008 and Nakajima et al., 2008). Results from these studies suggest that anammox bacteria can inherently prefer high salt concentrations and lives in high salt habitats and would be available for industrial purposes. Kartal et al., 2006 enriched fresh water Anammox bacteria candidatus kuenenia stuttgartiensis in a high saline reactor with salt concentrations of $30 \mathrm{~g} / \mathrm{L}$ and showed stable growth. For acclimatization phase for salt tolerance Yang et al., conducted lab scale experiments for 92 days in which reactor was feed with inorganic wastewaters with ammonia and nitrite with salt concentrations of $30 \mathrm{~g} / \mathrm{L}$ and reactor showed a stable NRR of $4.5 \pm 0.1 \mathrm{~kg}^{-\mathrm{Nm}^{-3}} / \mathrm{day}$. This was the first report of high salt tolerance.

\subsection{Biomass Concentration}

Apart from the above mentioned factors which effect ammonia remediation biomass concentration is also another contributing factor. Autotrophic nitrifiers contribute less biomass when compared to heterotrophic nitrification. It is always an important aspect that bulk amount of biomass is more efficient than less biomass with good ammonia removal efficiency. This might be the biggest disadvantage for anammox bacteria as the growth rate for these bacteria are very slow. Dapena Mora et al., used SBR to retain biomass of anammox and the results were successful with more ammonia removal. The highest removal rate of ammonia by anammox bacteria was reported by Sliekers et al., in a gas lift reactor with granular sludge was $8.9 \mathrm{kgN} / \mathrm{m}^{3} \mathrm{~d}$.

\section{Conclusion}

In this paper ammonia removal technologies are discussed in detail. Out of all technologies Anammox system was found to be feasible and extremely suitable for treatment of high concentrated ammonia containing industrial effluents. Anammox reduces additional carbon costs and aeration costs for industries unlike conventional nitrification and denitrification systems where operation at industrial level is more expensive. The main drawbacks for Anammox bacteria are their isolation in pure form and slow growth rate. Further research work is needed for Anammox isolation in pure form and for applicability of Anammox system for different industrial effluents.

\section{References}

[1] Abeling, U.; Seyfried, C.F. Anaerobic-aerobic treatment of potatostarch wastewater. Water science and Technology, 28 (2): 165-176, 1993.

[2] Ammonia in Ullmanns encyclopedia of Industrial Chemistry. Weinheim, Wiley-VCH, Max Appl, 2006.

[3] Antczak.S.A, Galas.E. Bacillus subtilis cells immobilized in PVA cryogels. Biomol Eng. 17: 55-63, 2001.

[4] Austermann-Haun, U.; Meyer, H.; Seyfried, C.; Rosen Winkel, K.H. Full scale experience with anaerobic/aerobic treatment plants in the food and beverage industry, Water science and Technology, 40 (1), 305-312, 1999.

[5] Bassin, J.P; Pronk, M.; Muyzer, G.; Kleerebezem, R.; Dezotti, M.; Van Loosdrecht, M.C.M. Effect of elevated salt concentrations on the aerobic granular sludge process:Linking microbial activity with microbial community structure. Appl Environ Microbiol, 77 (22): 7942-7953, 2011.

[6] Blackmer, A.M.; Bremner, J.M. Inhibitory effect of nitrate on reduction of $\mathrm{N} 2 \mathrm{O}$ to $\mathrm{N} 2$ by soil microorganisms. Soil Biol Biochem, 10: 187-191, 1978.

[7] Bonmati, A.; Flotats, X. Air stripping of ammonia from pig slurry: characterization and feasibility as a pre- and post treatment to mesophilic anaerobic digestion. Water manage, 23 (3): 261-272, 2002.

[8] Bonsen, E.M.; Schroeter, S.; Jacobs, H.; Broekaert, J.A.C. photo catalytic degradation of ammonia with $\mathrm{TiO} 2$ as photo catalyst in 
the laboratory and under the use of solar radiation. Chemosphere, 35, 1435-1445, 1997.

[9] Bravo, A.; Garcia, J.; Domenech, X.; Peral, J. Some aspects of photo catalytic oxidation of ammonium ion by titanium dioxide. $J$ Chem Res, 376-377, 1993.

[10] Brettar, I.; Labranz,M.; Flavier, S.; Botel, J.; Kousa,H.; Christen, R.; Hofle, M.G. Identification of Thiomicrospira denitrificans-like Eplisonproteobacterium as a catalyst for autotrophic denitrification in the central Baltic sea. Appl Environ Microbiol, 72: 1364-1372, 2006

[11] Brindle, K.; Stephenson, T. The application of membrane biological reactors for the treatment of wastewaters. Bio Technol Bioeng, 49: 601-610, 1996.

[12] Brouwer, M.; Van Loosdrecht, M.C.M.; Heijnen, J.J. One reactor system for ammonium removal via nitrite. STOWA report, 96-01, Utrecht, Netherlands, (ISBN 9074476 554).

[13] Camilla, G.; Gunnel, D. Development of nitrification inhibition assays using pure cultures of Nitrosomonas and Nitrobacter. Water Res, 35 (2): 433-440.

[14] Campos, J.L.; Mosquera-corral, A.; Sachez, M.; Mendez, R.; Lema, J.M. Nitrification in saline wastewater with high ammonia concentration in an activated sludge unit. Water Res, 36: 25552560, 2002.

[15] Campos, J.L.; Mosquera-corral, A.; Sachez, M.; Mendez, R.; Lema, J.M. Nitrification in saline wastewater with high ammonia concentration in an activated sludge unit. , 36: 2555-2560, 2002.

[16] Cannova, P.; Richaume, A.; Lafolie, F. Fate of nitrogen and carbon in the Vadose zone: insitu and laboratory measurements of seasonal variations in anaerobic respiratory and denitrifying activities. Soil Biol Biochem, 36: 463-478, 2004.

[17] Cema, G.; Wiszniowski, J.; Zebezynski, S.; Zablocka-Godldewska, E.; Raszka, A.; Surmacz-Gorska, J. Biological nitrogen removal from landfill leachate by deammonification assisted by heterotrophic denitrification in a rotating biological contactor (RBC). Water Sci Technol, 55: 35-42, 2007.

[18] Chang,Y.J.; Tseng, S.K. A double membrane system for simultaneous nitrification and denitrification in a single tank. Lett Appl Microbiol, 28: 453-456, 1999.

[19] Chemical engineering. News report on floral incident. Chemical engineering, July 1971, pp. 334. In Marshall, V.C.(1987) chemical Hazards. Ellis Horwood Ltd, ISBN 085312969X.

[20] Cho, E.; Molof, A. Effect of sequentially combining methanol and acetic acid on the performance of biological nitrogen and phosphorus removal. J Environ Manage, 73, 183-187, 2004.

[21] Chung, J.; Bae, W.; Lee, Y.; Ko,G.; Lee, S.; Park, S.; Investigation of the effect of free ammonia concentration upon leachate treatment by short cut biological nitrogen removal process in: IWA specialty symposium on strong Nitrogenous and Agrowastewater. Vol. 1, Seoul, Korea, June 11-13, pp. 93-104, 2003.

[22] Ciudad, G.; Rubilar, O.; Munoz, P.; Ruiz, G.; Chamy, R.; Vergara, C.; Jaison, D. Partial nitrification of high ammonia concentration wastewater as a part of short cut biological nitrogen removal process. Process Biochem, 40: 1715-1719, 2005.

[23] Cole, A.C.; Semmens, M.J.; Lapara, T.M. Stratification of activity and bacterial community structure in biofilms grown on membranes transferring oxygen. Appl Environ Microb, 70:19821989, 2004.

[24] Cuidad, G.; Rubilar, O.; Munoz, P.; Ruiz, G.; Chamy, R.; vergara, C.; Jeison, D. partial nitrification of high ammonia concentration wastewater as a part of short cut biological nitrogen removal process. Process Biochem, 40: 1715-1719, 2005.

[25] Cuidad, G.; Rubilar, O.; Munoz, P.; Ruiz, G.; Chamy, R.; vergara, C.; Jeison, D. partial nitrification of high ammonia concentration wastewater as a part of short cut biological nitrogen removal process. Process Biochem, 40: 1715-1719, 2005.

[26] Cyplik, P.; Grajek,W.; Merecik, R.; Kroliczak, P. Effect of macro/micro nutrients and carbon sources over the denitrification rate of haloferax denitrificans archaeon. Emzyme Microbiol Technol, 40, 212-220, 2007.

[27] Dalsgaard, T.; Thamdrup, B. Factors controlling anaerobic ammonium oxidation with nitrite in marine sediments. Appl Environ Microbiol, 68: 3802-3808, 2002.

[28] Daniel, L.M.; Pozzi, E.; Foresti, E.; Fabio Alexendre Chinalia, A. Removal of ammonium via simultaneous nitrificationdenitrification nitrite short cut in a single packed bed batch reactor. Bioresour Technol, 100, 1100-1107, 2009.

[29] Dapena Mora, A.; Fernendez, I.; Campos, J.I.; Mosquera-corral, A.; Mendez, R.; Jetten, M.S.M. Evaluation of activity and inhibition effects on anammox process by batch tests based on the nitrogen gas production. Enzyme Microbiol Technol, 40 (4): 859865, 2007.

[30] Della monica, M.; Agostizno, A.; Ceglie, A. An electrochemical sewage treatment process. J Appl Electrochem, 10, 527-533, 1980.

[31] Deng Petersen,P.; Jensen,K.; Lyngsie, P.; Hendrik, N.; Johansen. Nitrogen removal in industrial wastewater by nitration and denitration-3 years of experience, Water science and Technology, 47 (11): 181-188, 2003.

[32] Dhamole,P.B.; Nair,R.R.; D souza, S.F.; Lele, S.S. Gentrification of high strength wastewater. Bioresour Technol, 98: 247-252, 2007.

[33] Dosta, J.; Fernendez, I.; Vazquez-padin, J.R.; Mosquera-corral, A.; Campos, J.L.; Mata Alvarez, J.; Mendez, R. Short and long term effects of temperature on the anammox process. $J$ of Hazard Master, 154: 688-693.

[34] Egli, K.; Fanger, U.; Alvarez, P.J.J.; Siegrist, H.; Van der meer, J.R.; Zehnder, A.J.B. Enrichment and characterization of an annamox bacterium from a rotating biological contactor treating ammonium rich leachate. Arch Microbiol, 175 (1): 198-207, 2001.

[35] Feleke, Z.; Sakakibara, Y. A bio electro chemical reactor coupled with adsorber for the removal of nitrate and inhibitory pesticide. Water Res 36, 3092-3102, 2002

[36] Feng, Y.; Tseng, S.; Hsia, T.; Ho C chou, W. Partial nitrification of ammonium- rich wastewater as pretreatment for anaerobic ammonium oxidation (Anammox) using membrane aeration bioreactor. J of Bio Sci Bioengin 104: 182-187, 2007.

[37] Fliermans, C.B.; Bohlool, B.B.; Schmidt, E.L. Detection of Nitrobacter in natural habitats using fluorescent antibodies. Appl Microbiol, 27: 124-129, 1974.

[38] Foglar, L.; Briski, F.; Sipos, L.; Vukovic, M. High nitrate removal from synthetic wastewater with the mixed bacterial culture. Bioresour Technol 96, 874-888, 2005.

[39] Gill, K.I.; Choi, E.Nitrogen removal by recycle water, Nitration as an attractive for retrofit technologies in municipal wastewater treatment plant. Water science and Technology, 49 (5-6), 39-46, 2004.

[40] Gomez, M.A.; Galvaz, J.M.; Hontoria, E.; Gozalez,-Lopez, J. Influence of concentration on biofilm bacterial composition from a denitrifying submerged filter used for contaminated ground water. J Bio Sci Bioeng, 95, 245-251, 2003.

[41] Gonz, Z.; Yang, F.; Liu, S.; Bao, H.; Hu, S.; Furukawa, K Feasibility of a membrane- aerated biofilm reactor to achieve single-stage autotrophic nitrogen removal based on anammox. Chemosphere, 69:776-784, 2007.

[42] Gonzalez, L.E.; Canizares, R.O.; Baena, S. Efficiency of ammonia and phosphorus removal from a Colombian agro industrial wastewater by the microalgae Chlorella vulgaris and Scenedesmus dimorphus. Bioresour Technol, 60: 259-262, 1997.

[43] Gootzen, J.F.E.; Wonders, A.H.; Visscher, W.; Van Santen, R.Q.; Van Veen, J.A.R.A. DEMS and cyclic voltammetry study of NH3 oxidation on platinized platinum. Electro chem. Acta, 431852 1861, 1998.

[44] Groeneweg, J.; Sellner, B.; Tappe, W. Ammonia oxidation in Nitrosomonas at NH3 concentrations near Km: effects of $\mathrm{pH}$ and temperature. Water Res, 28 (12): 2561-2566, 1994.

[45] Guo, H.; Zhou, J.; Su, J.; Zhang, Z. Integration of nitrification and denitrificationin air lift bioreactor. Biochem Engin J, 23: 57-62, 2005.

[46] Guo, J.; Peng, Y.; Wang, S.; Zheng, Y.; Huang, H.; Wang, Z. Long term effects of dissolved oxygen on partial nitrification performance and microbial community structure. Bioresour Technol, 100:2796-2802, 2009.

[47] Hao, X.D.; Van Loosdrecht, M.S.M. Model based-evaluation of COD influence on a partial nitrification-anammox biofilm (CANON) process. Water Sci Technol, 49: 83-90, 2004.

[48] Hill, B.C.; Khan, E.A. Comparative study of immobilized nitrifying and co-immobilized nitrifying and denitrifying bacteria for ammonia removal from sludge digester supernatant. Water Air Soil poll, 195: 23-33, 2008.

[49] Hill, D.R.; Webster, T. High $\mathrm{pH}$ inhibits nitrifying bacteria. American water works association, 21-22, 2008.

[50] Holgene, J.; Bader, H. Ozonation of water: Kinetics of oxidation of ammonia by ozone and hydroxyl radicals. Environ Sci Technol, 12, 79-84, 1978.

[51] Imajo, U.; Tokutomi, T.; Furukawa, K. Granulation of anammox microorganisms in up flow reactors. Water Sci Technol, 49: 155163, 2004. 
[52] Isaka, K.; Sumino, T.; Tsuneda, S. High nitrogen removal performance at moderately low temperature utilizing anaerobic ammonium oxidation reactions. J Bio Sci Bioeng, 103; 486-490, 2007.

[53] Isaka,K.; Date, Y.; Sumino, T.; Yoshie, S.; Tsuneda, S. Growth characteristics of anaerobic ammonium-oxidizing bacteria in an anaerobic filtered reactor. Appl Microbiology and Biotechnology. 70: 47-52, 2006.

[54] Jenicek, P.; Svehla,P.; Zebranska, J.; Dohanyos, M. Factors affecting nitrogen removal by nitration/denitration, Water science and Technology, 49 (5-6): 73-79, 2004.

[55] Jetten, M.S.M.; Strous, M.; Van de pas schoonen, K.T.; Schalk, J.; Van Dongen, U.G.J.M.; Van de Graaf, A.A.; Longmann, S.; Muyzer, G.; Van Loosdrecht, M.C.M.; Kunen, J.G. The anaerobic oxidation of ammonium. FEMS Microbiology Reviews, 22, 421437, 1999.

[56] Kalyuzhnyi,S.; Gladchenko, M. Sequenced anaerobic aerobic treatment of potato starch wastewater, water science and Technology, 28 (2): 165-176,1993.

[57] Kartal, B.; Koleva, M.; Arsov, R.; Vander star, W.; Jetten, M.S.M.; strous, M. Adaptation of freshwater anammox population to high salinity wastewater. J Bio Technol, 126: 546-553, 2006.

[58] Kartal, B.; Rattray, J.; Van Niftrik, I,A.; Van de vossenberg, J.; Schmid, M.I.; Webb, R.I.; Schouten, S.; Furest, J.A.; Damste, J.; Jetten, M S.M.; Strous, M. Candidatus "Anammoxoglobus propionicus" a new propionate oxidizing species of anaerobic ammonium oxidizing bacteria. Syst Appl Microbiol, 30 (1): 39-49, 2007.

[59] Kartal, B.; Van Niftrik, A.H.; Sliekers, O.; Schmid, M.C.; Schmidt, I.; Van de pas schoonen, K.; Cirpus, I.; Van de star, W.; Van Loosdrecht, M.; Abma,W. et al. Application eco-physiology and bio diversity of anaerobic ammonium-oxidizing bacteria. Rev Environ Sci Bio/Technol, 3 (3): 255-264.

[60] Keller, J.; Subramaniam, K.; Gosswein, J.; Greenfield, P. Nutrient removal from industrial wastewater using single tank sequencing batch reactor. Water science and Technology, 35 (6): 137-144, 1997.

[61] Kim, J.K.; Park, K.J.; Cho, K.S.; Nam, S.; Park, T.; Bajpai, R. Aerobic nitrification- denitrification by heterotrophic Bacillus strains. Bioresour Technol 6, 1897-1906, 2005.

[62] Kim, K.; Kim, Y.; Kim, I.; Park. G.; Lee, E. Electrochemical conversion characteristics of ammonia to nitrogen. Water Res, 40, 1431-1441.

[63] Koenig, A.; Liu, L.H. Use of lime stone for $\mathrm{pH}$ control in autotrophic denitrification: continous flow experiments in pilot scale packed bed reactors. J Bio Technol, 99: 161-171, 2002.

[64] Kowalchuk, G.A.; Stephen, J.R. Ammonia oxidizing bacteria: a model for molecular microbial ecology. Annu Rev Microbiol. 55: 485-529, 2001.

[65] Kroschwitz,I, and Howe-Grant, M. (Eds). Kirk-othmer encyclopedia of chemical technology, $4^{\text {th }}$ edition, Vol 2:638-691, 1995. John wiley and sons Inc., New York, Chichester, Bristbane, Toronto, Singapore.

[66] Kuai, L.; Verstraete, W. Ammonium removal by the OxygenLimited Autotrophic Nitrification-Denitrification system. Appl Environ Microbiol, 64 (11): 4500-4506, 1998.

[67] Kwanyong, L.; Lee, C.G. Nitrogen removal from wastewaters by Microalgae without consuming organic carbon sources. $J$ Microbiol Biotechnol, 12 (2): 979-985, 2002.

[68] Lai, E.; Senkpiel, S.; Solly, D.; Keller, J. Nitrogen removal of high strength wastewater via nitration/denitration using a sequencing batch reactor. Water Sci Technol, 50, 27-33, 2004.

[69] Lapara, J.M.; Cole, A.C.; Shanahan, J.W.; Semmens, M.J. The effect of organic carbon, ammonical-nitrogen, and oxygen partial pressure on the stratification of membrane aerated biofilms. $J$ Ind Microbiol Biotechnol, 33: 315-323, 2006.

[70] Lindsey, M.R.; Webb, R.I.; Strous, M.; Jetten, M.S.M.; Butler, M.K.; Forde, R.J.; Fuerst, J.A. Cell compartmentalization in planctomycetes: Novel types of structural organization for the bacterial cell. Arch Microbiol, 176 (6): 413-429, 2001.

[71] Ma, L.; Sun, X.; Liang, X.; Cui, C. Biological nitrogen removal by nitrification-denitrification constructed rapid infiltration land system to treat municipal wastewater. J Food Agri Environ, 7 (3\&8): 795-798, 2009.

[72] Mansell, B.O.; Schroeder, E.D. Hydrogenotrophic denitrification in a micro porous membrane bioreactor. Water Res, 36:4683-4690, 2002.
[73] Marshall,V.C.; Major chemical hazards, Ellis Harwood Ltd, 1987, ISBN 085312969X.

[74] Metcalf and Eddy. Wastewater engineering: treatment and reuse, $4^{\text {th }}$ edition, Mc., Graw-Hill Co., New York, 2003.

[75] Morita, M.; Kudo, N.; Uemoto, H.; Watanable, A.; Shinozaki, H. protective effect of immobilized ammonia oxidizer and phenoldegrading bacteria on nitrification in ammonia and phenol containing wastewater. Eng Life Sci 7: 587-592, 2007.

[76] Mulder, A,; Van de graaf, A.A.; Robertson, I.A.; Kunen, J.G. Anaerobic ammonia oxidation discovered in a denitrifying fluidized bed reactor. FEMS Microbiol Ecol, 16 (3): 177-184, 1995.

[77] Mulder, J.W.; Van Loosdrecht, M.C.M.; Hellinga, C.; Van Kimpen, R. Full scale application of the SHARON process for the treatment of rejection water of digested sludge dewatering. Water Sci Technol, 43 (11): 127-134, 2001.

[78] Mulder, J.W.; Van Loosdrecht, M.C.M.; Hellinga,C.; Van Kempen, R. Full scale a[pplication of the SHARON process for the treatment of rejection water of digested sludge dewatering. Water Sci Technol, 43 (11): 127-134, 2001.

[79] N.Sivaraman and Geeta sivaraman, Research news, Current Science, Vol. 84, No. 12, 25 $5^{\text {th }}$ june, 2003.

[80] Nakajima, J.; Sakka, M.; Kimura, T.; Furukawa, K.; Sakka, K. enrichment of anammox bacteria from marine environment for the construction of a bioremediation reactor. Appl microbiol Biotechnol, 77: 1159-1166, 2008.

[81] Nielson, M.; Bollmann, A.; Sliekers, O.; Jetten, M.S.M.; Schmid, M.; Strous, M.; Schmidt, I.; Larsen, L.H.; Nielson, L.P.; Revsbech, N. Kinetics, diffusional limitation and micro scale distribution of chemistry and organisms in a CANON reactor. FEMS Microbiol Ecol, 51: 247-256, 2005

[82] Obaja, D.; Mace, S.; Costa, J.; Sans, C.; Mata-Alvarez, J. Nitrification-denitrification batch reactor. Bio resour Technol, 87, 103-111, 2003.

[83] Osaka, T.; Shirotani, K.; Yoshie, S.; Tsuneda, S. Effects of carbon source on denitrification efficiency and microbial community structure in a saline wastewater treatment process. Water Res 42, 3709-3718, 2008.

[84] Park, H.D.; Noguera, D.R. Evaluating the effect of dissolved oxygen on ammonia-oxidizing bacterial communities in activated sludge. Water Res, 38: 3275-3286, 2004

[85] Peng,Y.Z.; Chen, T.; Tian, W.J. Nitrogen removal via nitrite at normal temperature in A/O process. J Environ Sci Health, part A, Environ Sci Eng, 39 (7): 1667-1680, 2003.

[86] Penton, C.R.; Devol, A.H.; Tiedje, J.M. Molecular evidence for the broad distribution of anaerobic ammonium oxidizing bacteria in fresh water and marine sediments. Appl Environ Microbiol, 72 (10): 6829-6832, 2006.

[87] Peyton, B.M.; Mormile, M.R.; Peterson, J.N. Nitrate reduction with Halomonas campisalis: kinetics of denitrification at $\mathrm{pH} 9$ and 12.5\% Nacl. Water Res, 35: 4237-4242, 2001.

[88] Philips, S.; Laanbrock, H.J.; Verstraete, W. Origin causes and effects of increased nitrite concentrations in aquatic environments. Reviews in environmental science and Biotechnology, 1: 115-141, 2002.

[89] Poo, K.; Jun,B.; Lee, S.; Woo, H.; Kim, C. Treatment of strong nitrogen swine wastewater at a full scale sequencing batch reactor. Water science and Technology, 49 (5-6): 315-323, 2004.

[90] Princic, A.; Mahre, I.; Megusar, F.; Paul, E.A.; Tiedje, J.M. Effects of $\mathrm{pH}$ and oxygen and ammonium concentrations on the community structure of nitrifying bacteria from wastewater. Appl Environ Microbiol, 64 (10): 3584-3590, 1998.

[91] Reginatto, V.; Teixeira, R.M.; Pereira, F.; Schmidell, W.; Furigo Jr, A.; Menes, R.; Etchebehere, C.; Soares, H.M. Anaerobic ammonium oxidation in a bioreactor treating slaughterhouse wastewater. J Brazillan Chem Engin, 22 (4): 593-600, 2005.

[92] Rejn,J.V.; Tal, Y.; Schreier, H.J. Denitrification in recirculating systems: theory and applications. Aquacul Eng, 34: 364-376, 2006

[93] Rezania, B.; Olesz kiewi, Z.J.A.; Cicek, N. Hydrogen dependent denitrification of water in an anaerobic submerged membrane bioreactor coupled with a novel hydrogen delivery system. Water Res. 41: 1074-1080, 2007.

[94] Risgaard, S.; Glud, R.N.; Risgaard-peterson, N.; Dalsgaard, T. Gentrification and anammox activity in Arctic marine sediments. Limnol Oceanogr, 49: 1493-1502, 2004.

[95] Risgaard, peterson, N; Langezaal, A.M.; Ingvardsen, S.; Schmid, M.C.; Jetten, M.S.M.; Op den camp, H.J. Metal evidence for 
complete denitrification in a benthic foraminifer. Nature 443:9396, 2006.

[96] Rittmann,B.E.; Mc Carty P.L. Environmental biotechnology. Principles and applications 10020, Mc Graw-Hill, NewYork, NY; 2001.

[97] Rostron, W.M.; Stuckey, O.C.; Young, A.A. Nitrification of high strength ammonia wastewaters: Comparative study of immobilization media. Water Res, 35:1169-1178.

[98] Schmid, M.; Walsh, K.; Webb, R.; Rijpstra, W.I.C.; Van de pas schoonen, K.; Jan verbruggen, M.; Hill, T.; Muffet, B.; Furest, J.; Schouten, s.; et al. "Cnadidatus scalindua Brodae", sp nov., "Candidatus scalindua wagneri", sp nov., two new species of anaerobic ammonium oxidizing bacteria. Syst Appl Microbiol, 26 (4): 259-538, 2003.

[99] Schmid, M.C.; Risgaard-peterson, N.; Van de vossenberg, J.; Kuypers, M.M.M.; Lavik, G.; Peterson, J.; Hulth, S.; Thamdrup, B.; Canfield, D.; Dalsgaard, T.; Rysgaard, S.; Sejr, M.M.; Strous, M.; de camp, H.J.M.O.; Jetten, M.S.M. Anaerobic ammonium oxidizing bacteria in marine environments: wide spread occurrence but low diversity. Environ Microbiol, 9: 1479-1484, 2007.

[100] Schmidt, I.; Van spanning, R.J.M.; Jetten, M.S.M. Denitrification and ammonia oxidation by Nitrosomonas europaea wild-type,and NirK and NorB-deficient mutants. Microbiol, 150: 4107-4114, 2004.

[101] Sezekeres, K.; Kiss, I.; Bejerano, T.T.; Soares, M.I.M. Hydrogen dependent denitrification in a two reactor bioelectro chemical system. Water Res 35, 715-719, 2001.

[102] Sinnighe Damste, J.S.; Strous, M.; Rijpstra,W.J.C.; Hopmans, E.C.; Geenevasen, J.A.J.; Van Duin, A.C.T.; Van Niftrik, L.A.; Jetten.MSM. Linearly concentrated cyclobutane lipids from a dense bacterial membrane. Nature, 419(6908): 708-712, 2002.

[103] Sliekers, A.O.; Derwort, N.; Gomez, J.L.C.; Strous, M.; Kunen, J.G.; Jetten, M.S.M. Completely autotrophic removal of nitrogen over nitrite in a single reactor. Water Res, 36:2475-2482, 2002.

[104] Sliekers, O.; Third, K.A.; Abma, W.; Kuenen, J.G.; Jetten, M.S.M. Canon and anammox in a gas lift reactor. FEMS Microbiol Lett, 339-344, 2003.

[105] STOWA. Treatment of nitrogen rich return flows of sewage treatment plants. Evaluation of Dutch pilot plant research projects (in Dutch). STOWA report, pp 95-08, 1995.

[106] Sun.J, Liu.J, Liu.Y, Li.Z. Optimization of Entrapping Conditions of Nitrifying Bacteria and Selection of Entraping Agent. Second International Conference on Environmental Science and Technology. IPCBEE. Vol.6. IACSIT press. Singapore, 2011.

[107] Strous, M.; furest, J.A.; Kramer, E.H.M.; Logemann, S.; muyzer, G.; g Van de pas-schoonen, K.T.; Webb, R.; Kunen,, J.G.; Jetten, M.S.M. Missing lithotroph identified as planctomycete. Nature, 400 (6743): 446-449, 1999.

[108] Strous, M.; Heijnen, J.J.; Kuenen, J.G.; Jetten, M.S.M.; and PQ. The sequencing batch reactor as a powerful tool for the study of slowly growing anaerobic ammonium oxidizing microorganisms. Applied Microbiology and Biotechnology, 50: 589-596, 1998.

[109] Strous, M.; Heijnen, J.J.; Kunen, J.G.; Jetten, M.S.M. The sequencing batch reactor as a powerful tool for the study of slowly growing anaerobic ammonium oxidizing microorganisms. Applied Microbiology and Biotechnoogy. 50, 589-596, 1998.

[110] Strous, M.; Kuenen, J.G.; Fuerst, J.A.; Wagner, M.; Jetten, M.S.M. The anammox case-a new experimental manifesto for microbiological co-physiology. Antonie Van Leeuwenhoek, 81 (1/4): 693-702, 2002

[111] Strous, M.; Kunen, J.G.; Jetten, M.S.M. Key physiology of anaerobic ammonium oxidation. Appl Environ Microbiol, 65 (7): 3248-3250, 1999.

[112] Strous, M.; Van gerven, E.; Kunen, J.G.; Jetten, M.S.M. effects of aerobic and micro aerobic conditions on anaerobic ammoniumoxidizing (Anammox) sludge. Appl Microbiol, 63 (6): 2446-3446, 1997.

[113] Strous, M.; Van gerven, E.; Ping, Z.; Kunen, J.G.; Jetten, M.S.M. Ammonium removal from concentrated waste streams with anaerobic ammonium oxidation (Anammox) process in different reactor configurations. Water Research, 31: 1955-1962, 1997.

[114] Sugiyama, S.; Yokoyama, M.; Ishizuka, H.; Sotowa, K.I.; Tomida, T.; Shigemoto, N. Removal of aqueous ammonia with magnesium phosphates obtained from the ammonium elimination of magnesium ammonium phosphate. J Colloid Interface Sci, 292 (1): 133-138, 2005
[115] Tal, J.E.M.; Watts, J.; Schreir, H.J. Anaerobic ammonium oxidizing (Anammox) bacteria and associated activity in fixedfilm biofilters of a marine recirculating aquaculture system. Appl Environ Microbiol, 72: 2896-2904, 2006.

[116] Teixeira, P.; Oliveira, P. Denitrification in a closed rotating biological contactor. Effect of disk submergence. Process Biochem, 37, 345-349, 2001.

[117] Terada, A.; Yamamoto, T.; Igarashi, R.; Tsuneda, S.; Hirata. Feasibility of a membrane-aerated biofilm reactor to achieve controllable nitrification. Biochem Eng J. 28, 123-130, 2006.

[118] Third, K.A.; Olav Sliekers, A.; Kunen, J.G.; Jetten, M.S.M. The CANON system (completely autotrophic removal of nitrogen over nitrite) under ammonium limitation: interaction and competition between three groups of bacteria. Syst Appl Microbiol, 24: 588596, 2001.

[119] Tsushmi, I.; Ogasawara, Y.; Kindaichi, T.; Satob, H.; Okabe, S. Development of high rate anaerobic ammonium oxidizing (Anammox) biofilm reactors. Water Res, 41 (8): 1623-1634, 2007.

[120] Uemoto, H.; Saiki, H. Nitrogen removal by tubular gel containing Nitrosomonas europaea and Paracoccus denitrificans. Appl environ Microbiol, 62 (11): 4224-4228, 1996.

[121] Uemoto, H.; Saiki, H. Nitrogen removal reactor using packed gel envelopes containing Nitrosomonas europea and Paracoccus denitrificans. Biotechnol Bioeng, 67; 80-86, 2000.

[122] Van de star, W.R.L.; Abma, W.R.; Blommers, D.; Mulder, J.W.; Tokutomi, T.; Strous, M.; Picioreanu, C.; Van Loosdercht, M.C.M Startup reactors for anoxic ammonium oxidation: experiences from the first full scale anammox reactors in Rotterdam. Water Res 42: 4149-4163, 2007.

[123] Van de star, W.R.L.; Miclea, A.I.; Van Dongen, U.G.J.M.; Muyzer, G.; Picioreanu, E.; Van Loosdrecht, M.CM. The membrane bioreactor,: a novel tool to grow anammox bacteria as free cells. Biotechnology and Bio engineering, 101:286-294, 2008.

[124] Van de vossenberg, J.; Rattray, J.E.; Geerts, W.; Kartal, B.; Van niftrik, K.L.;Van donselaar, E.G.; Sinninghe Damste, J.S.; Strous, M.; Jetten, M.S.M. Enrichment and characterization of marine anammox bacteria associated with global nitrogen gas production. Environ microbiol, 10 (11): 3120-9, 2008.

[125] Van dongen, U.; Jetten, M.; Jetten, M.S.M.; Van Loosdrecht, M.C.M. The SHARON Anammox process for treatment of ammonium rich wastewater. Water Sci Technol, 44 (1): 153-160, 2001.

[126] Van niftrik, K.A.; Fuerst, J.A.; Damste, J.S.S.; Kuenen, J.G.; Jetten, M.S.M.; Strous, M.; and IK. The anammoxosome: an intra cytoplasmic compartment in anammox bacteria. FEMS microbiology letter, 233: 7-13, 2004.

[127] Van Niftririk, L.A.; Sinninghe Damste, J.S.; Kunen, J.G.; Jetten, M.S.M.; Strous, M. The anammoxosome an intracytoplasmic compartment in anammox bacteria. FEMS Microbiology Letters, 233: 7-13, 2004.

[128] Verstraete, W.; Philips, S. Nitrification and denitrification process and technologies in new contexts. Environ Pollution, 102 (51): 717-726, 1998.

[129] Wade, A.; Maher, B.; Lawerence, I.; Davis, N.; Zoppou, C.; Bell, C. Estimating the allowable ammonia concentrations in wastewater treatment plant discharge to ensure protection of aquatic biota. Environ Technol, 19 (7): 749-754, 1998.

[130] Wan, D.; Liu, H.; Qu, J.; Lei, P.; Xiao, S.; Hou, Y. Using the combined bioelectro chemical and sulphur autotrophic denitrification system for ground water denitrification. Bioresour Technol, 100: 142-148, 2009.

[131] Wang, A.; Edwards, J.G.; Davies, J.A. Photooxidation of ammonia with titania-based heterogenous catalysts. Sol Energy, 52 459-466, 1994.

[132] Wyffels, S.; Boeckx, P.; Pynaert, K.; Zhang, D.; Van cleemput, O.; Chen, G.; Verstraete, W. Nitrogen removal from sludge reject water by a two stage oxygen limited autotrophic nitrification denitrification process. Water Sci Technol, 49 (5-6): 57-64, 2004.

[133] Yan, Y.; Hu, Y.Y. Partial nitrification to nitrite for treating ammonium rich organic wastewater by immobilized biomass system. Bioresour Technol, 100: 2341-2347.

[134] Yang, J.; Jhang, L.; Hira, D.; Fukuzaki,Y.; Furukawa, K. Anammox treatment of high salinity wastewater at ambient temperature.

[135] Yang, M.; Uesugi, K.; Myoga, H. Ammonia reaction in a bubble column by ozonation in presence of bromide. Water Res, 33, 1911-1917, 1999. 
[136] Yoshie, S.; Ogawa, T.; Mokino, H.; Hirosawa, H.; Tsuneda, S.; Hirata, A. Characteristics of bacteria showing high denitrification activity in saline wastewater. Lett Appl Microbiol, 42: 277-283, 2006.

[137] Zeng, H.; Zhang, T.C. Evaluation of kinetic parameters of a sulphur-limestone autotrophic denitrification biofilm process. Water Res, 39: 4941-4952, 2005.

[138] Zhang, X.; Zhou, G.; Guo, H.; Qu, V.; Liu, G.; Zhao, L. Nitrogen removal performance in a novel combined biofilm reactor. Process Biochem, 42: 620-626, 2007.
[139] Zhu, X.; Castleberry, S.R.; Nanny, M.A.; Butler, E.C. Effects of $\mathrm{pH}$ and catalyst concentration on photo oxidation of aqueous ammonia and nitrite in titanium dioxide suspensions. Environ Sci Technol, 39, 3784-3791, 2005.

[140] Zumft, W.G. Cell biology and molecular basis of denitrification. Microbial Mol Rev 61: 533-616, 1997. 